\title{
Advancing Life Projects: South African Students Explain Why They Come to FET
} COLLEGES

\author{
Lesley Powella \\ Simon McGrath \\ University of Nottingham
}

\begin{abstract}
Vocational Education and Training (VET) policy in South Africa is based on a narrow set of assumptions regarding the identity of learners and the reasons that they are in public further education and training (FET) colleges. These assumptions reflect an international orthodoxy about the centrality of employability that is located within what Giddens (1994) has described as "productivism", a view that reduces life to the economic sphere. Through exploring the stories of a group of South African public FET college learners' regarding their reasons for choosing FET colleges, this paper shows that VET is valued by these students for a range of reasons. These include preparation for the world of work, but also a desire to improve their ability to contribute to their communities and families; raise their self-esteem; and expand their future life possibilities. Thus, the paper advances the largely hitherto theoretical critique of productivist VET accounts by offering empirical evidence of counter-narratives.
\end{abstract}

KEYWORDS: Vocational Education and Training, South Africa, Further Education and Training colleges, employability

\section{Introduction}

The last decade has seen Vocational Education and Training (VET) moving to the centre of policies that aim to reduce unemployment and support social and economic development goals. As researchers and policy actors, we welcome this heightened interest in VET. However, we are also concerned that this new wave of interest in and optimism regarding VET is underpinned by a flawed theoretical understanding of VET's purpose and value, particularly in developing contexts. Anderson $(2003,2009)$ describes the shared paradigm that dominates VET policy and practice internationally as "productivism". Building on Giddens' (1994) development of this concept, he argues that this paradigm is built on two interrelated assumptions: the first being that "training leads to productivity, [which] leads to economic growth (training-for-growth)"; and the second being that "skills lead to employability [which] leads to jobs (skills-for-work)" and thereby reducing poverty and unemployment (McGrath, 2012b, p. 624). Both these assumptions are challenged by a growing body of literature that highlights the problems with these accounts for human well-being (McGrath, 2012b; Powell, 2012). Indeed, this is a major thrust of UNESCO's World TVET Report (UNESCO, 2013), which calls for a transformative approach to VET, that builds on but goes far beyond economic rationales.

Despite this, South African Further Education and Training (FET) college legislation, in line with VET policies internationally, is littered with the language of productivism. The FET Green Paper contains the word employment 26 times, whilst the word human potential or anything similar in meaning is mentioned briefly, and only once in the introduction. Terms such as "prepar[ing] learners adequately ... for productive employment" (DoE, 1998a), and ensuring that college learners "are provided with the skills they need to be productive" (DHET, 2012) abound in key policy texts.

\footnotetext{
a Correspondence can be directed to: ttzlp@nottingham.ac.uk
} 
As with other middle income countries, the South African policy narrative for FET colleges, which are institutions located at the crossroads between school and the world of work, is that they are to fuel economic development by providing the intermediate to higher level skills needs of industry. The Green Paper on Further Education and Training 1998 provided the central purpose of FET colleges as "contribut[ing] to the envisaged economic growth of the country" (Department of Education, 1998b, p.2). More recently, the 2012 Green Paper for Post School Education and Training, talked of expanding participation in order that "those entering the labour market are qualified and competent to take up the employment and income generating opportunities that exist and that will exist as the economy grows and changes in the future" (DHET, 2011, p. viii). While this is softened in later pages by the recognition of "other developmental and transformative goals", the overall emphasis of South African FET policy is on preparing learners for employability by developing an education and training system that is responsive to "the needs of both employers and learners in a fast-changing economic and industrial environment" (DHET, 2012, p.7).

Simultaneously, the FET colleges are to address increasing levels of unemployment, particularly youth unemployment and growing poverty by expanding access to relevant and high quality education and training that prepares learners for employability. This has led to a focus on expanding participation in public FET colleges, from the current 300000 to 1.4 million learners by 2014, and 4 million by 2030 (DHET, 2012). As part of the drive to increased enrolment, concerns about colleges' unattractiveness, and a desire to make public FET colleges 'institutions of first choice' (DoE, 2007) have become paramount.

Yet, very little is known about why students enrol at these colleges and even less from the perspective of learners. It is assumed that learner voices are not important as it is "obvious" what learners want - jobs now. This article problematises both the assumptions of South African policy and the dominant academic literature by taking the time to listen to the reasons given by South African FET college learners for their participation in FET colleges. This is not a story of choice, as is commonly portrayed in the literature as deciding between different pathways or institutions. Rather, it is about how they conceive of VET as a way of advancing their "life projects" (Archer, 2003). This process of listening to the learners uncovers a tension between their accounts and the orthodox productivist account. In critiquing the latter, we follow Anderson in noting that productivism has served to separate "work as the principal, if not exclusive, source of meanings and measure of value for human beings" (2003, p. 4) from other domains constitutive of human well-being and a valuable life (cf. Unwin, 2004; McGrath, 2012b). When the productivist logic is extended to VET, it assumes that students participate in VET purely to achieve the aptitudes and attitudes required for work. This generates a singular emphasis on a narrow "initiative" version of employability (Gazier and Houneman, 1999), which leaves little room for the role that education and training plays in preparing young people for the challenges and opportunities that they will face in their families, their communities and their workplaces.

Reviews of the research literature on South African FET colleges note that students have been much neglected (Powell, 2013; Wedekind, 2009). Students have largely been spoken for by large quantitative studies that focus on aggregate patterns of student enrolment (Powell and Hall, 2000, 2002, 2004; Cosser et al, 2011) or graduate employment (Cosser, 2003; Gewer, 2009). One exception is the qualitative studies undertaken under the auspices of the Colleges Collaboration Fund (CCF) in the late 1990s and early 2000s that drew on focus group interviews to determine the institutional capacity for transformation (Fisher et al., 1998; Jaff 2000). Another study, albeit an exception by default, were the letters received by the Human Sciences Research Council (HSRC) during a study surveying student destinations. In that study, students were asked to return their survey to the HSRC, and a few students took it upon themselves to include a letter providing further explanation of their experience in FET, and their opinions of the labour market (Cosser, 2003, p.102). "Please Mr Cosser", wrote one of these students, "help us to be heard because we (college students) are just whispering and searching in the dark" (Cosser, 2003, p.90). The letters submitted by these students were not a 
designed aspect of the project, but an unintended consequence thereof. Nonetheless, they express poignantly the deep desire by the learners 'to be heard', a desire to which this paper responds.

This need for learners to be heard is not just a South African issue, but one that relates to a wider international tendency in the academic as well as policy literature. Only a small body of international literatures exist that draws on students' perspectives. These include a literature on (1) pathways into, through, and out of VET (e.g., Hodkinson, 1997, 1999; Ball, Maguire and Macrae, 2000; Harris and Ramos, 2012); (2) students' perspectives on policy (e.g., Avis, Bathmaker and Parsons, 2002; Bidgood, Saebi and May 2006; Tanggaard, 2013); and (3) students' constructions of themselves (e.g., Colley et al., 2003). However, none of these literatures haves explicitly sought to understand students' motives in terms of the broader life projects that students believe their participation in VET will serve to further. Moreover, African literatures of this kind are missing.

The predominantly quantitative literature on South African FET colleges offers three characteristics. The first is that FET college learners come from 'poverty-stricken family environments' (Gewer, 2009, p.x). Within this construct, the poverty experienced by many vocational learners; their limited social, economic and educational resources; and the social stratifying effects of the academic-vocational divide, are all equally important. However, with this construct comes a tendency to downplay the agency of learners who manoeuvre, consciously deliberate and negotiate, both within themselves and together with others, the best option forward. Whilst accepting the impact of structural effects, we followed Ball, Maguire and Macrae (2000, p.18) in seeking to "avoid portraying the[se] young people as simply victims of their circumstances or pathologising - 'othering' - them".

The second characteristic is the assumed poor academic performance of the learners, reinforced by the assumption that these students have comparatively lower intellect as compared to those who have gone on an academic track. The South African version of this international phenomenon was strongly shaped by the history of colonialism and Apartheid which linked VET "with issues related to indigence, social and educational inferiority, and mental backwardness" (Badroodien, 2004, p.21). Rather than emphasising in VET "the importance of individual development and the ability to choose a satisfying occupation" (Winch, 2000, p.31), it has been perceived as providing instrumental training for lower paid and lower skilled work. Although we acknowledge the real and perceived structuring effects of VET, following Rose (2004, p.xviii), we argue that "the way we talk about it [intelligence and work] matters" as it shapes "the way people are defined and treated in the classroom, the workplace, and in the public sphere" (2004, pp.xiii-xvii).

A third characteristic of VET learners, dominant in the wider African VET literature, is that learners avoid VET in favour of an academic education (Foster 1965a, b). This tradition, based on surveys done by Foster in the late 1950s, argues that parents and students regarded VET as terminal in nature and that it prepares learners for unemployment or for work that is repetitive, boring and underpaid. This assertion is bolstered by rates of return analysis (e.g., Psacharopoulos, 1991) that purport to show that these attitudes are not prejudices but a rational economic reading of the returns to vocational as opposed to academic education. Whilst such data is hugely outdated and has been subjected to widespread critique, the reality appears to matter very little. What is clear is that the perception of a "parity of esteem" issue continued to be widespread (see Minister Nzimande, 2009).

Besides the dominant strands of literature on learners mentioned above, another strand of South African writing related to FET colleges exists, but this too does not engage with student voices. Rather, it is a political economy account of the way that policies and practices fail to make a meaningful difference in a context of major structural effects (e.g., McGrath, 2004; Kraak, 2008; Allais, 2012). We are very aware of the ways in which the histories of colonialism and Apartheid and the historical processes of engagement with, and disengagement from, global capitalism have shaped the South African labour market and, hence, skills development. However, our purpose here is to go beyond this literature, which is limited in its sense of the possible ways in which learners understand these structural obstacles and the ways in which they seek to make agentic moves that tie into their aspirations for a better life. 
The dominating effect of the combined quantitative and political economy accounts has restrained South African VET researchers from grappling with the complexity inherent in the choices that learners actively make to participate in public FET. The result is that we have almost no understanding - and none from the lived experience of students - of why students are in FET. In starting to develop such an understanding, this paper breaks significant new ground, not just in the specific context of South Africa but in the wider context of debates about VET and development. It complements the theoretical arguments of recent articles (McGrath, 2012b; Powell 2012) and the transformative thrust for VET policy advocated by UNESCO, but this paper goes a step further by engaging seriously with learners' voices.

To do this, the article draws on one strand of a series of repeat interviews with 20 students and graduates drawn from various programmes and campuses of one public South African FET college, undertaken for Powell's doctorate. The study did not attempt to achieve representivity. Rather it drew on a wide cross section of students across ten programmes who after being presented with the details of the study elected to participate. As a part of the first interview session, students were asked to reflect on their reasons for enrolling at the college. We were interested in finding out what was important to them and how they believed enrolling at the college and in the specific programme area would help them achieve their life project(s). Here we follow Archer in seeing a life project as "an end that is desired, however tentatively and nebulous, and some notion, however imprecise, of the course of action through which to accomplish it" $(2003$, p.6). We were aware that structural constraints impacted on the lives of these learners but wanted to move beyond the over-structured stereotypes of learners presented above which tended to deprive students of agency and ignored the practical projects that individuals subjectively define in relation to their structural circumstances. In reflecting on why students elected to enrol at the FET college, we know that their choices were often fallible and their agency constrained. However, these are not our prime concern. Rather, we wanted to acknowledge students' individual and highly subjective 'constellation of concerns' (Archer, 2003) and the specific life projects that led them to see public FET colleges as a viable route for them.

In what follows, we do not seek to offer a richly theoretical account. Though Powell's thesis suggests how critical realism and the capabilities approach can offer a valuable new way of thinking about VET (Powell, 2014), our intention here is to offer stories that implicitly talk back to the dominant account, but to do so by privileging learner voices over theoretical debates. Nonetheless, we will come back to the theoretical significance of the article in the final section.

\section{Public FET Colleges Advancing Individual Life Projects}

All respondents shared the overriding hope that enrolling at the college would provide the education and training (or at least a part thereof) required to live a good life. Respondents differed though on what they considered this 'good life' to be. Rewarding and fulfilling employment was seen by all the respondents as fundamental to achieving this good life and was common to all their motives for enrolment. However, 'rewarding' and 'fulfilling' was conceptualised variably as: (1) the ability to work in an area in which they excelled; (2) contributing to their community; (3) being self-employed; and (4) securing work in a large corporation. Beyond the need to learn and to study further, students provided eight reasons for their college enrolment, five of which are emphasised for discussion in this paper. These reasons were complexly arranged. Some stressed multiple and equally important reasons; others a sole reason; whilst others still clearly ranked various reasons. In exploring this complexity, we have attempted to draw on students' voices as much as possible. However, it is important to note that the use of quotations and biographical details from any particular learner under certain headings neither denotes it as their sole reason for enrolment, nor does it signify that it may not be a shared sentiment among the learners. 


\section{"A lot more hands on": College as Offering a Better Learning Model}

At 18, Sinazo (all names are pseudonyms) has passed her National Certificate Vocational (NCV) level 4 in Business Management at the FET college and was enrolled, at the college, for a Nated programme in Finance, Economics and Accounting. Sinazo was encouraged to enrol at the FET college by a college recruiter who visited her school. At that time she attended a highly rated school but was attracted by the idea of a programme that mixed theory and practice and that was "a lot more hands on" than school. Sinazo's mother, a domestic worker who had not completed high school herself, agreed to her enrolment only after being assured that this would not limit Sinazo's ability to enrol for university study in the future.

Sinazo's attraction to the hands-on aspect of college programmes was driven by her desire to work in the finance sector, preferably in a large company, and to be financially independent in the future. Her life project is to "have my own house ... not sure where, but somewhere peaceful" and to "live together with my mother". Like most other students in the sample, Sinazo was raised in a single parent household and feels strongly that she would "love [for her] mother to come and live with [her]" so that she can "take care of her" when she is old.

Like Sinazo, Andile decided to attend the college after a college recruiter visited his school. Without parents to consult, he sought guidance from a school teacher who advised him that going to the college is a chance "to start now for [your] dreams" rather than defer this to after Grade 12. Based on the information provided by the college recruiter and his teacher's guidance, Andile decided to leave school after Grade 9 and to enrol at the college for the NCV in Mechanical Engineering. Andile believed that the combination of theory and practice offered at the college would help him achieve his ambition of being accepted for, and then successfully completing Mechanical Engineering at a local technical university.

Sinazo's and Andile's cases contradicted the impression that FET college students would rather have an academic education. There were no social, economic or academic push factors prompting either Andile or Sinazo to leave school. In fact, Sinazo left school to enrol at the college despite her mother's initial opposition. In fact, in terms of academic performance, both students reported doing reasonably well at school. While on average, Sinazo scored Cs for all her subjects, Andile scored an average of a $\mathrm{C}+$ with an occasional $\mathrm{B}$, particularly in pure maths and physical science.

For both these students, the movement to the FET college was a calculated and strategic decision designed to take their respective life projects forward more effectively than attending school would have been able to. Sinazo's life project was that it would enable her to move into a business context with the 'hands on' experience required to succeed therein, whilst protecting her long term ambitions for university. As for Andile, he aspires to enrol and succeed in a mechanical engineering degree.

\section{"I went with the wrong crowds": College as a Space for Rehabilitation}

Unlike Sinazo and Andile, who were pulled into college, Francois and Aisha were pushed into college to get away from the negative influence of peers. Aisha described herself as becoming delinquent by mixing "with the wrong crowds". Hearing about the college from a family member, Aisha's mother brought her to the college to have a look around. At first glance Aisha was unconvinced and "told [her] mommy, 'no matter how nice the college looks I'm still not going to attend it because I want to be at [my old] school'". But upon further inspection and interaction with the college staff members, "it got [her] thinking". In light of the high numbers of unemployed school and university leavers, she decided that college might be a practical choice for her as it would allow her to study masonry which, in turn, would make it possible for her to "hook into a job [with her] aunty and them [who] have their own company". 
In another case, Francois was addicted to 'tik' (crystal methamphetamine). His enrolment was prompted by his need to get away from his drug using peer group. He was one of the four students (25\%) who spoke of the effect of personal drug or alcohol use, and one of 14 who live in or near areas severely affected by drugs and gangsterism. As said by Francois, "the only people that I knew were those people, because there weren't really much other people. Then I started hanging out with them and then I got influenced". After spending time in rehab he decided that it would be best to not return to the school again:

Using drugs ... that became a big mistake in my life because due to that, that's also why I failed at school. I failed one of my grades. That was grade nine. Then I went back and redid it, but it was quite challenging for me because everybody that I used to know were still at the school. So, I had to totally block myself from everybody.

Francois has now graduated from the NCV programme, been drug free for over three years, and is happily in full-time employment doing work that he finds rewarding. He is currently enrolled parttime on a N5 programme at the college in the same discipline with financial support from his company.

For both Aisha and Francois, the need to distance themselves from their delinquency had important consequences for their educational path, and the choices they made therein. In both cases the FET college provided them with a viable route forward.

\section{"I like to work with my hands": College as a Route to Artisanal Work}

Thomas was the only white student who participated in the study. 30 years ago the campus site at which Thomas is currently enrolled catered mainly for young white South African men who had completed their military service. Like the rest of the FET college sector in South Africa, black students are now the majority on campus.

However, for Thomas coming to the college was a personal choice as his father trained to be a fitter and turner at the same campus 45 years ago. Thomas came to the college after completing his Grade 9 as he "wanted a technical matric". Following in his father's footsteps, he enrolled for a NCV in Fitting and Turning. Thomas's sees his father's life as an artisan as having been successful as he progressed to management level in a large company, enabling him to secure a middle class life for his family. Thomas aspires to the same trajectory of work and life. He described the college as "the best place for me" as it "works at my pace and it just works out for me".

Similarly, Jorge decided prior to enrolling at the college that he would like to be a mechanical engineer. He represents one of five students in this study (25\%) who came to the college because they decided to work in a particular trade. Jorge's decision was influenced by his grandfather and step-father.

My grandfather, he used to work on cars, so that inspired me a lot as well and my step dad as well. He's a technician. So he showed me all the things I need to know about the computers, software and everything. So then I got more pleasure from that so I said, 'okay this is the field that I want to go into'.

Previously Jorge was studying at a highly rated school and enjoyed the sporting facilities at the school, particularly for playing rugby and soccer. He indicated that his real ambition had been to pursue a career in professional sports, but his family was against the idea so he opted for mechanical engineering instead. His long-term goal is to work offshore on a rig working on large machinery. Jorge described his school grades as "good, it was just my Afrikaans wasn't so good but my grades were really good". He has successfully completed his NCV in Mechanical Engineering, and is now employed full-time while being enrolled part-time at a different college for his N5 in Mechanical 
Engineering. Having discovered that these programmes were not discontinued, as he was informed, he regrets in retrospect that he did not complete Grade 12 and says that, "if [he] knew [that he] would have just finished that one year and then gone on to do my N4".

In support of employability accounts, both these learners shared a common desire to obtain the education and training needed to access suitable work in their chosen fields. For them, VET can advance their life projects, as it is the route to their chosen occupations.

\section{"I was getting paid as a boy": College as a Route to Career Mobility}

Seven years after Jacob left high school he returned to full time education at the college for a NCV in Electrical Infrastructure Construction. Contrary to the findings of Middleton, Ziderman and Adams (1993) who argue that youth do not aspire to VET, the opportunity to study at the college was "a dream come true" for Jacob. In his early years, he lived in an area that Lemanski (2009) describes as "virtually derelict", which was occupied by people "squatting in the non-serviced informal settlement" and those who are homeless (2009, p.10). At that time, he regularly travelled past the college which during Apartheid excluded black students and catered then only for white students and decided that "[he is] going to come to this college" one day. The historical exclusion under apartheid of black students from technical training made this a college to which he aspired to be in.

Jacob's decision to study at the college was prompted by his experience in a big company that he worked in prior to enrolling at the college. He worked as a senior technician, but did not earn a commensurate salary, nor enjoy the appropriate status. After three years at the company and having a salary increment and an advance in job title only once over his three years tenure, he realised that he would need to study further in order to progress beyond "getting paid as a boy", as he put it. Realising that "it [was] either working for this company for the rest of [his] life, slowly growing or [leaving and going to study and] growing at a decent pace", he gave his notice and enrolled at the FET college.

Similarly, Alfred was triggered to enrol by the way that he was treated in his job. As an assistant chef in a large catering company prior to enrolling, he felt that he was being treated as "just a boy" by his supervisor.

My one supervisor, this lady was, she's also, ok, I don't want to be racist, but she is also white and she was the head-chef in the kitchen. She was like treating me also like, okay, you just working here, you're just a boy. You must just do this and do that. And I didn't really like it, but I had to do it... that was all things that made me realize that I need to come to FET or somewhere. I need to go and study, doing this course ... this hospitality course.

Both came into the college with a sense of vocational aspiration and a need to develop their identity. Alfred had studied hospitality at a high school where catering talent competitions were held. His initial plan was to complete Grade 12 and then to enrol in the Professional Cookery skills course offered at the college, but he was forced to drop out of school due to his father's demise. As said by Alfred,

[I had to leave school] because my dad died, nobody had work. My mom was the only person that could work, and I had a small brother that time, so I had to go look after him, take care of him. So that's why [I left school].

When he first tried to enrol in the hospitality programme, he was initially unsuccessful as it was already full. Rather than undertake a different programme, he waited for another year and was successfully admitted. Conversely, Jacob's decision to enrol in the NCV for Electrical Infrastructure Construction was shaped by his experience with electrical work which was introduced to him by his uncle, a line of work which he soon "started to love". He regards himself as having a special talent for fixing things, a talent that was recognised and acknowledged by his family members. 
I love messing with electrical equipment ... anything that I can fix, I fixed. I try to. I still do it at home. My aunt or my mom them bring something and only if I can't fix it then they declare it broken.

Both Alfred and Jacob had to weigh up the benefits of leaving paid employment to enrol in full-time study. Applying their human powers of reflexivity, they deliberated and reflected on the circumstances of their work environment and decided that the work that they were doing was under-paid and under-valued. Most importantly, they "figured that this is how it is if you don't have papers [qualifications]". As said by Alfred,

I realised that if I'm not that qualified, this is what I'm gonna do and this is how I'm gonna suffocate. ... people treat you like they want to, you must do this, you must do that, go there, go here, do this, do that. You must be satisfied if you're not qualified and you want to work.

The decision to leave work for study was not an easy one for both learners. Jacob had left home at a young age and was at the time of the interview living on his own and had to be selfsufficient. Alfred, who lives in a family vulnerable to poverty, faced similar concerns as leaving fulltime employment would mean sacrificing an income for the household and, in doing so increasing the risk of dire poverty for the entire family.

Deviating from Jacob who was encouraged by his fiancé to take the leap, Alfred grappled internally with the problem in the initial stages. As he said, "I realised I need to go and study further and that was always a thing in the back of my mind ... you need to go, you need to go" and he kept asking himself in light of the structural constraints affecting him and his family, "So how am I gonna do it?". After discussing the problem with a friend, he was encouraged to "go and do [his] studies" despite the opportunity risks discussed above. This became an event which Alfred denoted as a turning point in his life.

In both cases, strong structural circumstances shaped these students' lives prior to their enrolment in the FET college. For one, both grew up in poverty and in single parent households. In addition, both experienced difficulties completing their schooling. Jacob attempted to make up for this by completing his schooling part-time and prior to enrolling at the college by enrolling in another short course. However, despite their circumstances, both these young men have managed to go beyond the education level of their families and communities. As said by Jacob, "I'm the first one out of the lot who is studying, either side, from my mom's family and my dad's family". In doing so, both these young men are trying to circumvent the structural constraints in which they grew up in. Having left employment to enrol at the college, they are aware of the risk at which they have placed their families and themselves in, yet it is a risk they deem worthy of undertaking. As said by Alfred,

People know ... if you live ... in xxx, where I live, people normally don't see you come out on the top standard ... our environment where we live, isn't such a good environment.

Against the backdrop of a racially defined labour market, both Jacob and Alfred are concerned not only with employment that is sustainable and that pays a decent salary, as employability accounts would have, but also with working in environments that are respectful. But they are also both ambitious and concerned to make a wider contribution. Alfred aspired to becoming one of the top pastry chefs in his area. But another, and equally important aspect for him, is to become "something in life", and getting "qualified to become something in this country also, [so that you can have the ability] to contribute".

Additionally, they were committed to helping their families. Jacob indicated that, "[he] want to make sure that [his] kids or the kids of the next generation would have an easier life or better 
life to what I have", while Alfred spoke of supporting his younger sibling with his education. Beyond that, both were committed to wider social responsibility. As said by Alfred,

[I want] to help people with their struggles and to encourage people. They need to know that they are not the only persons who always have problems and that other people also have problems and they can do it [educate themselves], because I did it.

Similarly, Jacob echoed these sentiments by saying,

I don't want to be rich, I don't want to be. I just want to be healthy and wealthy enough to take care of myself and my family. I'm not a greedy person I don't want everything in the world. But I want to know that I can bring to my country or to my place of work, I can bring with me energy, I can bring with me ideas of how to change.

\section{"I had to take responsibility and upgrade myself": College as a Vehicle for Meeting Familial and Community Responsibilities}

At 38, Daphne is the oldest student in the college's NCV Business Management programme. Regretting her decision to "drop out [of] school at a young age", her decision to enrol was part of a long-term commitment to her education. It began when she strived to complete her schooling part-time while looking after her three children.

After being a housewife for over a decade, there were two key factors that prompted her to enrol at the college. Firstly, her husband was unemployed and the family was struggling financially with the absence of a breadwinner in the family. Secondly, her daughter had failed her Grade 12 examination and, having become a young mother at the same time, was demoralised about returning to education and about the possibility of making a success of her life. Under these circumstances, Daphne wanted to set an example for her daughter and husband and at the same time was hoping to re-enter the labour market, an act that would allow her to contribute financially to her family. As Daphne mentioned, when talking about her daughter,

I can be big example for her because she can see like I was, dropped out at like a young age.

And here I am trying again.

Daphne indicated that one of her biggest challenge in life was her low self-esteem, which was described as a result of "the way we're brought up ... the [physical] ... and alcohol abuse at home". Besides encouraging her husband and daughter, enrolling at the college was an enormous opportunity for her to develop her self-esteem. As shown below, it provided a special opportunity for her to transform her own life;

I had like a low image of myself ... I was like, I can do nothing ... I can just be a housewife.

But everything changed, the day I believed in myself, accepted myself, everything changed.

Daphne believed that having a low self-esteem is common amongst black women who "think they cannot do it, [in terms of their education] and that they cannot do something for themselves". She is hoping that the business management skills gleaned from her NCV programme will prepare her for employment in a position that would enable her to encourage other women facing similar financial constraints. More importantly, and with her family on the verge of destitution, she is hoping that her achievements will encourage her family to be more positive about their outlook in life.

In another case, Lubabalo was also prompted to enrol due to his desire to be a better parent and to transform his life. Previously he had worked as an unqualified assistant to a cabinet maker, 
but when he became a father he was prompted to "make a change" in his life. He realised that he "would have to take [up] a career":

I reached a point in my life whereby I wanted to make a change and I realised in order for me to make a change, I must undergo some training in what I enjoy doing, which is working with my hands. I had to take responsibility and upgrade myself.

Lubabalo has made a conscious choice to work with his hands, driven by his religious views. He argued that working with your hands is not only spiritually fulfilling, but it assures that you'll always have work as others prefer to "sit behind a desk and do this and press that and answer the phone" rather than "build the building to work in, or make the table to work on".

Initially, Lubabalo's preference was to enrol in a boat-making programme offered at another campus, but he was deterred by the additional daily travel costs. Therefore, he chose to enrol in an alternate course, that is, the NCV Engineering \& Related Design: Fitting. As was the case with Daphne, Lubabalo's aim was broader than accessing the skills required for employment. In both cases, it was evident that the need to set an example for others, particularly their children, became a big motivating factor that triggered their enrolment. Lubabalo realised that, as a father, he would need to set an example and provide for his son. While for Daphne, being confronted with her husband's and daughter's loss of confidence, had prompted her into action in the attempt to them that it is possible to pick your life up at any point and transform it for the better. While productivist thinking focuses on the skills needed for economic growth, and on the importance of employment, Daphne's motive are focused on her family and on community development.

In a related case, Makukhanye's motivation for enrolling at the college was to be prepared for work through the adoption of the shortest and most secure route. Reading about the college for the first time from a magazine, he decided that it would be better for him to leave high school and to enrol at the college for a NCV in Finance, Economics and Accounting because "[he] thought that it will help [him get] ready for the workplace".

However, Makukhanye's aims are broader than accessing skills for employment. Rather, employment is a means to achieve "a better living standard" in order to help support his family:

I must do something to help as well, to help with the children, the schooling. I must give something back to them. I mean, they [his family] have not told me so, but I know that is how it goes. You can't receive all the time and expecting and not giving anything out. It's an inner thing, it is not supposed to be said to you, but it's what you know [to be right].

\section{"Here by default": College as a Bounded Choice}

The stories above give a sense of agency, even if this is profoundly shaped by past life histories and by socio-economic circumstances. However, for some of the learners in the sample, even this level of agency seemed unattainable. Whilst not the primary focus of this paper, we must acknowledge the realities of this group of interviewees.

In one case, we had Warren whose grades had allowed him to pass his school leaving examinations but not enough to get him into higher education. He spent a year "looking, looking, looking for work" and "got so frustrated" that his fiancée persuaded him to enrol. Encouraged by the fact that he can cook, they decided that he should enrol for catering. Along with Siyaya, another interviewee, who also completed his school leaving examinations with grades too low for higher education, they form part of an estimated half million young South Africans who had completed Grade 12 without having the grades or subjects required for higher education. Along with these half million youth, they are part of a larger group of 2.8 million young South Africans who policy makers have termed NEET (Not in Education, Employment or Training) (Cloete, 2009). 
Apart from the reason above, there were others for whom the college was a bounded choice. Sharon and Carol both had the grades for university but couldn't afford the fees. Carol explained that she was at the college "by default" as she had left employment where she was hoping to save up the money for higher education study and lacking any other plan decided to enrol at the FET college. Whereas for Mulhim, a wheelchair user, the college was the most viable place for further learning, both in terms of its accessibility and its inclusive approach.

\section{Conclusion}

The findings of this article suggest that the orthodox position taken on why young people enter FET in South Africa (but also internationally) is profoundly limited. Drawing on the voices of students exhibited in the sections above, we see three messages emerging.

First, the findings challenge the stereotype prescribed to VET students that has dominated much of the literature. The idea that college students choose FET colleges because they recognise that they are unable to cope with the academic rigours of schooling was challenged by the experience of several students. Indeed, contrary to the literature that sees VET in Africa as second choice, and second best (Foster, 1965a and b; Psacharopoulos, 1991 and Oketch, 2007), half of this study's interviewees actively chose to leave 'academic education' to enrol at the FET college.

Second, the findings highlight the limitations of productivist accounts which portray these students as empty slates enrolling in FET colleges in the anxious hope that they will be filled with the skills needed to become productive future workers. While it is clear that learners seek to prepare themselves for the world of work, we are reminded that learners enrol in VET for much more complex and varied reasons than the orthodoxy acknowledges (cf. Unwin, 2004 in the British context). They come into VET as daughters wanting to financially support their families; as fathers wanting to be an example to their daughters; as workers wanting to upgrade their skills; as community members wanting to encourage other members of their community, and for other reasons besides.

Third, and most importantly for our immediate purposes, it shows that at least some FET students, in contrast to the orthodox account, are active and deliberatively engaged in electing to study at a FET college. This is not an attempt to argue away the social constructs embedded within the curriculum, location and structure of FET or to deny the social constraints that face the learners and the communities in which they live. Rather, it is an attempt to highlight the agency of these learners and the manner in which learners experience, participate and respond to the structural circumstances of their lives. These students are enterprising in the face of structural circumstances. They are choosing between school and college; between staying at home and enrolling at the college. They are electing to leave employment in order to study at the college and then choosing for all the reasons that matter to them, the programme areas that they enrol in. In some cases, decisions appear to us to have been made fallibly, reflecting both misunderstandings of the complex policy changes and $\mathrm{HE}$ admission practices by learners and/or the college, and sometimes due to misinformation from the college. These learners are, as Bynner et al. (1977) argued, "getting on" and "getting by" and only the future will tell if they are getting somewhere or "going nowhere".

In this article, we have been determined to highlight learners' voice and agency. This is not an attempt to deny structural factors. Rather, our intention here is to deliberately challenge a limited orthodoxy that consistently underplays learner agency. This led us to the strategic decision to downplay structure's role, although we remain mindful of its power. Structure was present across the transcripts. The learners spoke of poverty, the persistence of race in labour market stratification, the effects of single parent families, inequalities in access to quality schooling, and the challenges of living in areas rife with drugs and gangsterism. Their lives are powerfully shaped by the legacies of an Apartheid-defined racial geography that forces many into a localism shaped by issues of cost, time and safety of travel (McQuaid, Green and Danson, 2005) that requires some to travel considerable distances to the college. 
These college students are real people with real needs and aspirations. Many have been affected by poverty, have made poor choices, or have not realised their full educational and human potential. But they have made choices, often in thoughtful and principled ways, and according to life plans that they have reason to value. They do not conform to the stereotypes of the orthodox literature and we argue that VET theory, policy and practice should build from their lived experiences rather than on fallacies and two dimensional simplifications about them. As the Nigerian novelist, Adichie (2009) reminds us, there is a danger in a single account:

There is a danger in the single story ... a single story creates stereotypes, and the problem with stereotypes is not that they are untrue, but that they are incomplete. They make one story, become the only story.

By refusing the established single story, this article offers an important step towards a deeper account of why learners choose VET, for choose it many do. It adds empirical support, though from a limited sample from a specific context, to more theoretical and policy-oriented accounts that seek to stress that VET is, and must be seen as being about ways of building human well-being that incorporate but go far beyond employability and economic rationales.

\section{Notes}

Our gratitude goes to the principal and the staff of the college at which the study was based and to the students who shared so much of their lives.

\section{References}

Adichie, C. (2009). The Danger of a Single Story. Available at: http://www.ted.com/talks/ chimamanda_adichie_the_danger_of_a_single_story.html [Accessed 1 October 2009].

Allais, S. (2012). Will skills save us? Rethinking the relationship between vocational education, skills policies, and social policy in South Africa. International Journal of Educational Development, $32(5), 632-642$.

Anderson, D. (2003). Productivism, VET and ecological sustainability. Paper presented to The Changing Face of VET, $6^{\text {th }}$ Annual Conference of the Australian VET Research Association, Australian Technology Park Conference Centre. 9-11 April, Sydney.

Anderson, D. (2009). Productivism and ecologism: Changing discourses in TVET. In J. Fien, R. Maclean, \& M. Park (Eds), Learning and Sustainable Development: Opportunities and Challenges. Bonn, Germany: Springer, pp.147-162.

Archer, M. S. (2003). Structure, Agency and the Internal Conversation. Cambridge: Cambridge University Press.

Avis, J., Bathmaker, A., \& Parsons, J. (2002). Communities of practice and the construction oflearners in post-compulsory education and training. Journal of Vocational Education and Training, 54(1), 27-50.

Badroodien, A. (2004). Technical and vocational education provision in South Africa from 1920 to 1970. In S. McGrath, A. Badroondien, A. Kraak \& L. Unwin (Eds.), Shifting Understandings of Skills in South Africa Overcoming the Historical Imprint. Pretoria: HSRC Press, pp.20-45.

Ball, S., Maguire, M. \& Macrae, S. (2000). Choice, Pathways and Transitions Post-16:. New youth, new economies in the global city. London: Routledge Falmer.

Bidgood, P., Saebi, N., \& May, S. (2006). Influences on student withdrawal from further education: a case study. Journal of Vocational Education and Training, 58(2), 223-236.

Bynner, J., Ferri, E., \& Shepherd, P. (Eds.). (1977). Twenty-Something in the 1990s. Aldershot: Ashgate.

Cloete, N. (2009). Responding to the Education Needs of Post-School Youth. Wynberg: Centre for Higher Education Transformation. 
Colley, H., James, D., Tedder, M., and Diment, K.. (2003). Learning as becoming in vocational education and training : class, gender and the role of vocational habitus. Journal of Vocational Education and Training, 55(4), 471-498.

Cosser M, Kraak, A., Winnaar L., Reddy,V., Netshitangani T. and Twalo, T. (2011). Further Education and Training (FET) Colleges at a Glance: FET Colleges Audit. Pretoria: Human Sciences Research Council.

Cosser, M. (2003). Graduate tracer study. In M. Cosser, S. McGrath, A. Badroodien, \& B.Maja, (Eds.). Technical College Responsiveness: Learner Destinations and Labour Market Environment in South Africa. Cape Town: HSRC Press, pp.27-55.

Department of Education. (1998a). Further Education and Training Bill. Pretoria: Department of South Africa.

Department of Education. (1998b). Green Paper on Further Education and Training: Preparing for the twenty-first century through education, training and work. Pretoria: Department of Labour.

Department of Education. (2007). FET Colleges: Institutions of First Choice. Pretoria: Department of Education.

Department of Higher Education and Training. (2011). Green Paper for Post School Education and Training. Pretoria: Department of Higher Education and Training.

Department of Higher Education and Training. (2012). Green Paper for Post-Secondary Education and Training. Pretoria: Department of Higher Education and Training.

Fisher, G., Hall, G., \& Jaff, R. (1998). Knowledge and Skills for the Smart Province: An agenda for the new millennium. Johannesburg: National Business Initiative.

Foster, P. (1965a). Education and Social Change in Ghana. London: Routledge and Kegan Paul.

Foster, P. (1965b). The vocational school fallacy in development planning. In C.Anderson \& M.Bowman (Eds), Education and Economic Development. Chicago: Aldine.

Gazier, B. \&Houneman, S. (1999). Employability: an evolutionary notion, an interactive concept. In B. Gazier (Ed.), Employability. Berlin: European Employment Observatory Research Network, pp.3-23.

Gewer, A. (2009). Features of social capital that enhance the employment outcomes of FET college learners. Unpublished PhD thesis. University of Witwatersrand.

Giddens, A. (1994). Beyond Left and Right. Cambridge: Polity.

Harris, R., \& C. Ramos. (2012). The one less travelled: adult learners moving from the academic sector to the vocational sector in Singapore and Australia. Journal of Vocational Education and Training, 64(4), 387-402.

Hodkinson, P. (1997). Contrasting models of young people's career progression. In J. McNielle (ed.) Careers Guidance: Constructing the Future. Richmond: Trotman/Institute of Careers Guidance, pp.3-13.

Hodkinson, P. (1999). Use of habitus, capital and field in understanding young people's career decision making. In M. Grenfell \& M. Kelly (Eds.), Pierre Bourdieu: Language, Culture and Education. Bern: Peter Lang. pp. 259-269.

Jaff, R. (2000). A Situational Analysis of FET Institutions. Johannesburg: National Business Initiative.

King, K. (2012). The geopolitics and meanings of India's massive skills development ambitions. International Journal of Educational Development, 32(5),665-673.

Kraak, A. (2006). The challenge of the 'second economy' in South Africa: the contribution of skills development. Journal of Vocational Education and Training, 57 (4), 429-452.

Kraak, A. (2008). A critical review of the National Skills Development Strategy in South Africa. Journal of Vocational Education and Training, 60 (1), 1-18.

Lemanski, C. (2009). Spaces of exclusivity or connection? Linkages between a security village and its poorer neighbour in a Cape Town master plan development. Cape Town: Islandla Institute. 
Lumby, J. (2000). Technical colleges in South Africa: planning for the future. Journal of Vocational Education and Training, 52(1), 101-118.

McGrath. S. (1998). National policies and institutional practices: the credibility gap in South African education and training reform. Journal of Vocational Education and Training, 50 (4), 503-518.

McGrath. S. (2004). Reviewing the development of South African Further Education and Training college sector ten years after the end of apartheid. Journal of Vocational Education and Training, 56 (1), 137-160.

McGrath, S. (2012a). Building new approaches to thinking about vocational education and training and development: Policy, theory and evidence. International Journal of Educational Development, 32 (5), 619-622.

McGrath, S. (2012b). Vocational education and training for development: a policy in need of a theory? International Journal of Educational Development, 32 (5), 623-631.

McQuaid, R., Green, A. \& Danson, M. (2005). Introducing employability. Urban Studies 42 (2), 191-195.

Middleton, J., Ziderman, A, \& Adams, A. (1993). Skills for Productivity. Vocational Education and Training in Developing Countries. New York: Oxford University Press, The World Bank.

Nzimande, B. (2009). Change views of FET, speech delivered to the South African Students Congress. Available at: http://www.news24.com/SouthAfrica/Politics/Nzimande-Change-view-ofFETs-20091207. [Accessed on 25 June 2014]

Oketch, M., (2007). To vocationalise or not to vocationalise? Perspectives on current trends and issues in technical and vocational education and training (TVET) in Africa. International Journal of Educational Development, 27 (2), 220-234.

Powell, L. (2012). Reimagining the purpose of VET. Expanding the capability to aspire in South African further education and training students. International Journal of Educational Development, 32 (5): 643-653.

Powell, L. (2013). A critical assessment of research on South African further education and training colleges. Southern African Review of Education, 19(1), 59-81.

Powell, L. \& G. Hall. (2000). Quantitative Overview of South African Technical Colleges - 1998. Johannesburg: National Business Initiative.

Powell, L. \& G. Hall. (2002). Quantitative Overview of the Further Education and Training colleges - A sector in transition. Johannesburg: National Business Initiative.

Powell, L. \& G. Hall. (2004). Quantitative Overview of the Further Education and Training College Sector: The new landscape. Pretoria: Department of Education.

Powell, L. (forthcoming). Reimagining the purpose of Vocational Education and Training: The perspectives of Further Education and Training College students in South Africa. Unpublished PhD Thesis, University of Nottingham.

Psacharopoulos, G. (1991). Vocational education theory, VOCED 101: Including hints for 'vocational planners'. International Journal of Educational Development, 11 (3), 193-199.

Rose, M. (2004). The Mind at Work: Valuing the Intelligence of the American Worker. New York: Penguin Books.

Tanggaard, L. (2013). An exploration of students' own explanations about dropout in vocational education in a Danish context. Journal of Vocational Education and Training, 65(3), 422-439.

UNESCO. (2013). World Report on Technical and Vocational Education and Training. Paris: UNESCO.

Unwin, L. (2004). Growing beans with Thoreau: rescuing skills and vocational education from the UK's deficit approach. Oxford Review of Education, 30 (1), 147-160.

Wedekind, V. (2009). Report on the Research on Further Education and Training (FET) Colleges in South Africa. Output of the England-Africa Partnerships in Higher Education. Durban: University of Kwazulu Natal.

Winch, C. (2000). Education, Work and Social Capital: Towards a New Conception of Vocational Education. London and New York: Routledge. 